УДК 347.451 .41

DOI $10.21661 / \mathrm{r}-461895$

\title{
А.А. Себякина
}

\section{ЮРИДИЧЕСКАЯ ПРИРОДА ДОГОВОРА КУПЛИ-ПРОДАЖИ БУДУЩЕЙ НЕДВИЖИМОСТИ}

Аннотация: в статье на основе судебной практики и работ практикующих юристов проведен анализ юридической природы и особенностей договора купли-продажи недвижимости, которая будет построена в будущем. В статье сделан вывод о том, что договор купли-продажи будущей недвижимости является разновидностью инвестииионных договоров, который наиболее часто встречается в юридической практике. Результаты анализа могут применяться при структурировании инвестиционных отношений в сфере строительства недвижимости.

Ключевые слова: инвестиционные отночения, инвестиционный договор, купля-продажа недвижимости, строительство.

\section{A.A. Sebyakina}

\section{LEGAL NATURE OF REAL ESTATE SALE AND PURCHASE CONTRACT}

Abstract: in the article, based on the court practice and studies of practicing lawyers, the analysis of the legal nature and features of the sales contract about real estate, which will be built in the future, is carried out. The article concludes that the future real estate sales contract is a type of investment contracts, which is most frequently found in legal practice. The results of the analysis can be used when structuring investment relations in real estate construction.

Keywords: investment relations, investment contract, sale and purchase of real estate, construction.

Правильное структурирование отношений в сфере строительства недвижимости путем заключения того или иного договора имеет большое значение для минимизации рисков сторон и достижения эффективного результата. Однако не 
только сам выбор договорной формы участниками отношений по строительству недвижимости, но также и правильное толкование условий данного договора судами и применение эффективных способов защиты прав сторон предопределяют успешную реализацию строительного проекта. Важность анализа юридических конструкций оформления отношений по строительству предопределяется также и экономическим контекстом - приобретение прав на недвижимость еще на стадии ее строительства является более выгодным по сравнению с приобретением этой же недвижимости после ее сдачи в эксплуатацию. Сложность регулирования таких отношений на практике заключается в том, что для оформления прав на строящуюся недвижимость и финансирования строительства сторонами чаще всего заключаются так называемые инвестиционные контракты, юридическая природа которых точно не определена действующим законодательством.

Прежде чем перейти к анализу одного и видов инвестиционных договоров договора купли-продажи будущей недвижимости, необходимо отметить следующее. Ни в судебной практике, ни в научной среде не было выработано единой юридической концепции квалификации договоров, заключаемых при инвестировании в строительство недвижимого имущества. Именно этот фактор сыграл решающую роль при принятии Высшим Арбитражным Судом РФ решения об издании Постановления Пленума №54 «О некоторых вопросах разрешения споров, возникающих из договоров по поводу недвижимости, которая будет создана или приобретена в будущем» (далее - «Постановление №54»), которое обобщило практику заключения инвестиционных договоров по поводу строящихся объектов и решило вопрос их юридической природы. На основе наблюдения за инвестиционными сделками, заключаемыми в сфере строительства и реконструкции недвижимого имущества, Постановление 54 описывает три договорных модели, которыми оформляются отношения сторон при осуществлении инвестиций в строящуюся недвижимость - договор купли-продажи вещи, которая будет создана или приобретена в будущем (которая будет создана, т.е. построена - применительно к отношениям в сфере строительства); договор строительного под- 
ряда; договор простого товарищества (совместная деятельность). Издание данного Постановления - это реакция на массовую застройку за счет бюджетных средств, когда неясна природа соглашений о строительстве; его целью является обеспечение баланса интересов сторон в отношениях по строительству, стабильности экономического оборота в целом. Важно отметить тот факт, что в Постановлении устанавливается опровержимая презумпция, согласно которой, пока не доказано иное, судам следует квалифицировать договоры, связанные с финансированием строительства и реконструкции объектов недвижимости как договоры купли-продажи. Этот вывод также основан на анализе судебной практики - большинство инвестиционных сделок в сфере строительства имеют меновой характер, когда на одной стороне лежит обязанность по созданию объекта недвижимости и его передачи в собственность, а на другой стороне - обязанность по оплате полученного объекта или его части. Однако ВАС РФ отнюдь не ограничивает сторон в выборе договорных форм отношений по поводу строительства недвижимости - стороны могут заключить как договор, содержащий в себе элементы нескольких указанных договоров, так и вовсе непоименованный в ГК.

Чаще всего на практике в последнее время при структурировании инвестиционных отношений участники гражданского оборота оформляют свои отношения посредством заключения договора купли-продажи недвижимости, которая будет создана (построена) в будущем. Как отмечается специалистами, возможность заключения таких договоров позволяет покупателю недвижимости привлекать финансирование еще на стадии ее строительства под залог прав по такому договору, что, на наш взгляд, способствует эффективному развитию инвестиций в строящуюся недвижимость. Договорная модель оформления отношений, при которой одна сторона договора (застройщик) обязуется передать объект недвижимости в собственность другой стороне (инвестору) после завершения строительства, а инвестор обязуется оплатить полученный объект, является наиболее распространённой на практике. Однако основные проблемы, которые могут возникнуть при заключении такого договора, связаны, во-первых, с проблемой индивидуализации объекта недвижимости, поскольку при заключении 
договора его невозможно детально индивидуализировать таким образом, как это предусматривается ст. 554 Гражданского кодекса РФ и выработано судебной практикой. Во-вторых, на момент заключения договора купли-продажи недвижимости, которая будет построена в будущем, право собственности продавца на такую вещь еще не зарегистрировано. Формально в п. 2 ст. 455 Гражданского кодекса РФ предусматривается, что договор купли-продажи может быть заключен как в отношении объекта, который имеется в наличии у продавца в момент заключения договора, так и в отношении объекта, который будет создан или приобретен продавцом в будущем. Несмотря на положения закона, российские суды уклонялись от прямого признания возможности заключения такого договора, и нередко признавали такие договоры ничтожными [12], во многом следуя германской традиции, согласно которой нельзя распорядиться вещью, право на которую еще не зарегистрировано продавцом [3, с. 56]. Учитывая такое положение вещей, на практике стороны чаще всего использовали конструкцию предварительного договора купли-продажи недвижимости, с которым связаны определенные риски и который в меньшей степени, чем договор купли-продажи, защищает интересы сторон.

Принятие Постановления №54 было призвано скорректировать судебную практику в этой области - данным Постановлением прямо указано на допустимость ситуации, при которой у продавца отсутствует право собственности на момент заключения договора. Как К.И. Скловский, появляется новое понятие недвижимой вещи - недвижимость, которая будет создана или приобретена в будущем. Можно выделить следующие существенные характеристики этой недвижимости как предмета договора купли-продажи: 1) на момент заключения договора недвижимость как объект сделки отсутствует, поскольку предполагается ее создание или приобретение к моменту передачи права собственности покупателю; 2) к моменту передачи права собственности на такую недвижимость, продавец обязан не только ее создать или приобрести, но и зарегистрировать свое право на данный объект в Едином государственном реестре недвижимости. Такой правовой режим будущей недвижимой вещи строится на необходимости 
дифференциации ее как особого объекта недвижимости, отличного от традиционного предмета договора купли-продажи и смежных с ним сделок [14, с. 112]. Недвижимая вещь, находящаяся в процессе создания, рассматривается как особый объект владения и согласно Проекту изменений Гражданского кодекса РФ. Признавая строящуюся недвижимую вещь объектом владения, Проект допускает распространение на нее владельческой защиты, что, на наш взгляд, укрепляет положение застройщика, независимо от договорной модели, оформляющей его отношения с инвестором.

Более сложным с практической точки зрения является вопрос о способах индивидуализации предмета договора купли-продажи будущей недвижимости. При продаже уже построенного и зарегистрированного, учтенного объекта недвижимости главным способом его индивидуализации является указание кадастрового номера, однако при заключении договора в отношении будущей недвижимости, могут возникнуть проблемы. Согласно Постановлению 54, индивидуализация будущей недвижимости возможна путем указания сведений, позволяющих определить недвижимое имущество, подлежащее передаче по договору. В качестве таких сведений указывается местонахождение возводимой недвижимости, ориентировочная площадь будущего здания или помещения, иные свойства, в том числе определенные с использованием проектной документации. Однако в случае существенного расхождения характеристик готового объекта недвижимости с теми, которые были указаны при заключении договора, существует риск признания его незаключенным, поэтому на практике вопросу индивидуализации нужно уделять пристальное внимание. Главная проблема заключается именно в существенности расхождений характеристик объекта недвижимости.

На основе анализа судебной практики были выявлены следующие аспекты проблемы индивидуализации будущей недвижимости в договорах. Во-первых, отсутствует единство судебной практики в вопросе о существенности расхождений в площади построенного объекта и той площади, которая была согласована сторонами при заключении договора. Так в одном деле разница в метраже была признана судом не существенной (на основе анализа проектной и технической 
документации) и иск о признании права собственности истца был удовлетворен [8]. В другом деле значительно меньшая разница в площади была признана существенным расхождением и договор был признан незаключенным [9]. Представляется, что решающим фактором при признании договора незаключенным в данном случае было то, что стороны не согласовали никакие другие характеристики будущего объекта недвижимости кроме его площади. Во-вторых, на практике стороны нередко индивидуализируют будущий объект недвижимости в дополнительном соглашении, что, по мнению некоторых юристов-практиков, является наиболее опасным способом индивидуализации для дальнейшей судьбы договора [1, с. 74]. В одних случаях суды признают такие договоры незаключенными, поскольку после утверждения проектной документации сторонами так и не было заключено дополнительное соглашение, индивидуализирующее объект недвижимости, подлежащий передаче в собственность инвестору. В другом деле при аналогичных обстоятельствах суд счел, что отсутствие дополнительных соглашений, индивидуализирующих объект недвижимости не дает основания признавать договор незаключенным, поскольку строительство дома только началось, а на момент заключения договора для сторон не имела значения конкретная площадь объекта и иные его характеристики [10]. В-третьих, также возможен вариант детализации объектов недвижимости в акте приема-передачи, однако существует и судебная практика признания таких договор незаключенными, ввиду отсутствии достаточной индивидуализации недвижимости в акте приема-передачи. Как мы видим, вопрос индивидуализации будущего объекта недвижимости имеет на практике решающее значение для дальнейшей судьбы договоров, что можно считать одним из существенных рисков оформления инвестиционных отношений по форме договора купли-продажи недвижимости, которая будет создана или приобретена в будущем.

Вопрос о моменте возникновения права собственности покупателя на построенный объект недвижимости по договору купли-продажи будущей недвижимости прямо следует из самой конструкции данного договора, который пред- 
ставляет собой договор о передачи вещи в собственность. При исполнении договора купли-продажи право собственности переходит к покупателю всегда только производным способом - то есть после регистрации этого права за продавцом (в большинстве случаев за застройщиком). В пользу данного тезиса говорит также и тот факт, что чаще всего именно застройщик по такому договору обладает правами на земельный участок, на котором строится недвижимость, поэтому первичное право собственности на построенный объект может возникнуть только у него. Установив производность права собственности покупателя на объект недвижимости, можно определить и те гражданско-правовые способы защиты, которые доступны ему в случае нарушения продавцом своих обязанностей по договору. В данном случае покупателю доступны следующие варианты защиты: 1) требование о возврате выплаченной денежной суммы и возмещении убытков (ст. 487 Гражданского кодекса РФ); 2) требование об исполнении обязательства в натуре - передачи недвижимой вещи и регистрации перехода права собственности (ст. 308, 551 Гражданского кодекса РФ) [2, с. 34]. Однако иск об исполнении в натуре обязательства продавца по передачи вещи в собственность покупателя возможен только в том случае, если объект недвижимости находится во владении продавца и его права собственности на этот объект зарегистрировано. Судебная практика подтверждает данный вывод [6]. Однако гораздо чаще на практике встречаются ситуации, когда объект построен, введен в эксплуатацию, однако первичная регистрация права собственности на него не произведена. Представляется, что в данном случае у покупателя есть право требовать первичной регистрации права собственности за продавцом, а затем - регистрации перехода права собственности к покупателю. Как было указано выше, именно такая модель защиты была закреплена в Проекте Постановления ВАС о внесении изменений в Постановление 54. Однако, опять же, использование таких способов защиты возможно только при условии, если ответчиком по такому иску является застройщик как сторона инвестиционного договора (договора купли-продажи будущей вещи); объект недвижимости построен на земельном участке, права на 
который принадлежат застройщику; объект недвижимости введен в эксплуатацию и не передан третьим лицам. Как было указано выше, вещно-правовые способы защиты, в частности иск о признании права собственности, недоступны инвестору. Также можно говорить и о том, что в некоторых случаях суды не удовлетворяют иски об исполнении обязательства по передаче построенной недвижимости в том случае, если она не введена в эксплуатацию и представляет собой объект незавершенного строительства [7].

Выше была рассмотрена ситуация, при которой объект недвижимости фактически построен застройщиком. Однако существенным отличием договора купли-продажи будущей вещи от, допустим, договора строительного подряда (который тоже используется на практике как договорная конструкция оформления отношений по строительству недвижимости, однако не является предметом нашего рассмотрения в данной работе) является возможность покупателя требовать непосредственно создания вещи. Поскольку предметом договора куплипродажи является передача собственности на объект от покупателя к продавцу, постольку при отсутствии построенной недвижимости права покупателя фактически не защищены. Этой позиции придерживается и А. Сергеев, который указывает на то, что «неоправданно положению, согласно которому ограничены права покупателя требовать вещи в натуре только тогда, когда вещь создана продавцом» $[13$, с. 42]. Также весьма интересной нам представляется точка зрения, согласно которой такой договор можно рассматривать как договор под отлагательным условием. При наступлении определенного сторонами условия (применительно к инвестиционным договорам в сфере строительства недвижимости этим условием является создание объекта недвижимости) у сторон автоматически появляются взаимные обязанности. У продавца - обязанность регистрации права собственности на недвижимость за собой и передача такой недвижимости покупателю, а у покупателя - обязанность оплаты такой недвижимости. Такой взгляд на юридическую природу договора купли-продажи будущей вещи еще раз доказывает слабость гарантий его исполнения до момента создания вещи - как 
нам представляется, этот фактор можно рассматривать как серьезный недостаток данной договорной конструкции.

Анализ проблем защиты прав покупателя (инвестора) по договору куплипродажи будущей недвижимости приводит некоторых специалистов к выводу о том, что единственной доступной ему гарантией является обеспечение обязанностей застройщика перед покупателем-инвестором ипотекой земельного участка или права аренды [4, с. 71]. Однако при таком обеспечении в случае привлечения для строительства кредитных средств может возникнуть риск того, что права на земельный участок уже заложены банку - в этом случае инвестор станет последующим залогодержателем. В случае дефолта застройщика (залогодателя), согласно п. 1 ст. 342 Гражданского кодекса РФ, инвестор (залогодержатель) получит удовлетворение только после обращения взыскания предыдущим залогодержателем (банком). Это, безусловно, несет в себе определенные риски для инвестора-залогодержателя. Следует отметить также, что очень часто застройщики обладают правами аренды на земельные участки, на которых осуществляется строительство. Но, как известно, арендное оформление отношений землепользования не является достаточно прочным ввиду подчинения договора аренды принципу договорной свободы, отсутствия минимального срока договора строительной аренды в законе. Поэтому представляется весьма перспективной и эффективной с точки зрения развития инвестиционных отношений в сфере строительства идея авторов Концепции развития законодательства о вещном праве о внедрении в российский гражданский оборот такого ограниченного вещного права как право застройки [5]. Такой шаг приведет к укреплению прав застройщика на земельный участок (ввиду срока права застройки, его вещного характера и т.д.), а также сделает более привлекательным для инвестора залог такого права с целью обеспечения обязанностей застройщика.

Представляется, что усовершенствованию механизма защиты прав покупателя по договору купли-продажи будущей недвижимой вещи и расширению способов получения покупателем конкретного недвижимого объекта будет способствовать принятие Проекта Федерального закона «О внесении изменений в части 
первую, вторую, третью и четвертую Гражданского кодекса Российской Федерации, а также в отдельные законодательные акты Российской Федерации» [11], которым закрепляется институт права приобретения чужой недвижимой вещи. Согласно п. 1 ст. 304.1 главы 20.5 данный институт применяется и к отношениям по поводу приобретения будущей недвижимой вещи. Эффективность данного института заключается именно в его вещно-правовой природе. Главным его достоинством является то, что обладатель такого ограниченного вещного права приобретения чужой вещи (в том числе будущей) помимо возможности требовать от продавца передачи конкретно определенной вещи может также истребовать данную вещь от любого третьего лица (в случае ее отчуждения продавцом по договору) независимо от добросовестности этого третьего лица. Также важным является и положение о возможности регистрации этого права в качестве обременения земельного участка, если вещь еще не создана. Представляется, что введение этого института в гражданский оборот усилит защиту прав инвесторовпокупателей будущей недвижимой вещи и восполнит недостатки обязательственных способов защиты их прав.

\section{Сиисок литературы}

1. Багаева А. Описание будущего объекта недвижимости в договоре. Как разрешаются спорные ситуации // Юрист компании. - 2012. - №7.

2. Бевзенко Р.С. Квалификация и последствия сделок с будущей недвижимой вещью. Комментарий к Постановлению Пленума ВАС РФ от 11 июля 2011 г. №54 «О некоторых вопросах разрешения споров, возникающих из договоров по поводу недвижимости, которая будет создана или приобретена в будущем» // Вестник ВАС РФ. - 2012. - №3.

3. Бычков А.И. Отчуждение будущих вещей и имущественных прав // Имущественные отношения в Российской Федерации. - 2012. - №7.

4. Коневский А. Договор на совместное строительство коммерческого объекта // Юрист компании. - 2013. - №7. 
5. Концепция развития гражданского законодательства Российской Федерации (одобрена решением Совета при Президенте Российской Федерации по кодификации и совершенствованию гражданского законодательства от 07.10.2009) // СПС «Консультант Плюс».

6. Определение ВАС РФ от 06.08.12 №BAС-9525/12 // СПС «Консультант Плюс».

7. Определение ВАС РФ от 09.04.13 №BAC-3556/13 // СПС «Консультант Плюс».

8. Постановление ФАС Поволжского округа от 01. 12.2015 по делу №A5715802/2010 // СПС «Консультант Плюс».

9. Постановление Третьего арбитражного апелляционного суда от 23.01.2013 по делу А33-8250/2012 // СПС «Консультант Плюс».

10. Постановление Одиннадцатого Арбитражного апелляционного суда от 16.02.12 по делу №A49-6834/2010 СПС «Консультант Плюс».

11. Проект Федерального закона «О внесении изменений в части первую, вторую, третью и четвертую Гражданского кодекса Российской Федерации, а также в отдельные законодательные акты Российской Федерации» // СПС «Консультант Плюс».

12. Решение Арбитражного суда г. Москвы от 12.04 .12 по делу №A4071609/10-82-612 // СПС «Консультант Плюс».

13. Сергеев А. Споры о будущей недвижимой вещи - дело прошлого? Закон. - 2011. - №9.

14. Скловский К.И. Сделка и ее действие. - М: Статут, 2012.

Себякина Анастасия Алексеевна - студентка ФГАОУ ВО «Национальный исследовательский университет «Высшая школа экономики», Россия, Москва.

Sebyakina Anastasia Alekseevna - student at the FSBEI of HE "National Research University "High School of Economics”, Russia, Moscow. 